\title{
THE FAMILY AND THE CITY: THEIR FUNCTIONAL RELATIONS.
}

\section{The Family as the Growing Point of the Social Structure.}

Leslie Stephen points out that, unlike every other association, the family is fundamental. In whatever special form it may exist, it always has its roots in the same instincts. "The family.... depends at once upon the most primitive instincts of our nature, which are the direct products of our organic constitution. The love of man and woman or of mother and child constitutes a bond which requires and admits of no further explanation by reference to other emotions. It is, of course, true that other instincts, and indeed every instinct of which we are capable, come to group themselves round this central instinct and strengthen the primitive tie. But that tie is more or less the ground of every other, the antecedent assumption in all human society, and, therefore, not explicable as a product of other modes of association." (Science of Ethics, p. I32.) He further adds, after indicating the immense social changes that may follow a change in the family mode, "And thus, from a scientific point of view at least, the family is not in any case the product of the political arrangement, but rather one of the primitive arrangements which determine the nature of the state." (op. cit., p. I33.)

The family thus creates the city; not the city the family. It is a common fallacy to place city and family on the same plane as if they were a larger and a smaller aggregate of the same kind. No mistake can be greater. The internal instincts or external pressures that bring together men into a city, may flow from the primary family instinct; but they are derived from it and do not produce it. It is legitimate to regard the city as a great family; but it is not legitimate to regard the family as merely a reduced city.

The functions of the city are not, as popular belief imagines, antagonistic to the functions of the family or alien to it; on the contrary, they grow out of it. The family instinct is their lifeblood, their motive power, their true form, their end.

Our hardened popular conceptions of institutions, as if they were but externally related to each other, will neither serve to unify our social theory, nor justify our social practice. One 
cannot help hearing the persistent wail that attends the present rapid transformation of parental responsibility, for example, into a higher form. In the modern world, from before the day when Social Statics, appeared, until now, we have not wanted for prophets to explain to us how the bonds of society must loosen and decay when the contemporary ethic of the family proceeds to assimilate new growths. I remember well with what perfect lucidity I seemed to see all Herbert Spencer's final reasons against the incipient movement towards public education, the incipient organisation of life amid the unspeakable welter of city slumdom. Nothing seemed more simple than that school boards were all a mistake, just as sanitary boards and practically all other boards were. The argument, if I remember rightly, went down even to the details of street paving and convinced us how infinitely preferable for the moral good of the individual it would be for him to put down his own part of the pavement rather than accept the same service from himself in his capacity as citizen. And Spencer's clearness of vision, his remorseless pushing of this theory to its limits, did a good service in its day; but, however much he may have affected the individual thinker, he did nothing to stop the movement towards representative institutions and the whole growth of modern local government is, it seems to me, antagonistic to his primary analysis in Social Statics. If no logic that admitted his own premises has successfully answered his conclusions, he has nevertheless been answered by the logic of history.

With all that has been said about the importance of the family, its functional service as the infant school of ethics, its primary significance in every society, I have no wish to disagree. Even if I suggest that, at the present moment, the current half-realised conception of the family as an isolated social unit, an atom, has failed, because that conception was itself a fiction, or rather a dissociated hypothesis, I do not, therefore, say that social regeneration from the very same roots is not possible. What has made, will unmake and remake. So long as there is a father, a mother and a child, so long will there be a family capable of creating a new society. So much we may take for granted. Here our point of view is different. What I wish to ask is what the family functionally is in our present civic society. 
II. The immediate end of the Family, and the necessary aggregation of Families in Clan, Village, Town, City.

The immediate end, or telos, of the family as a social molecule is to provide nurture for the child. Whether there be a child or not, it may be an advantage for the man and woman to constitute a unit under the same constancy of obligation as a true family of father, mother and child; but no one can say that the social significance of the obligation is on the same plane of importance in the two cases. Broadly, if there is no child, there is no family. At least, for our purpose, we may take this as the essential point. Broadly, therefore, the immediate end of the family is to provide nurture for the child.

But nurture cannot be provided without adequate mechanism. The primary necessities of the new-born infant are warmth and food. Up to a point, these may both be provided by the mother's person alone; but she in turn demands nurture to keep her fit to be the support of her child. Whatever may have been the case in the early history of mankind, or in tropical climates, there is no question now as to the primary necessities of man as he lives in Western Europe: in order to provide for his child, he must procure food and shelter for the mother. Shelter means housing; food means proteids, carbohydrates, fats, water and salts. The building of a house involves labour; labour involves food-seeking by the labourer; food-seeking in solitude is profitless except where the earth produces adequate food. Where it does not, foodseeking involves the co-operation of other social units. The family of three that can live absolutely alone, unrelated to any other three-group, is rare in the modern world, - so rare that it cannot be regarded as the normal family. As a country fills up with men, the conditions demand greater and greater struggle; food-seeking is more difficult, yet more imperative; labour is less remunerative, yet more essential to success. Gradually, the solitary family must starve or leave the home in order to seek another family that both may survive. The aggregation of families we can see going on to-day as simply and as inevitably as we see it in imagination among primitive men. And if a single child of one father and mother means this necessary fight to wrest food and warmth from nature, a second and third and fourth child only intensify the necessity for struggle. Hence we have the farm, with its labourers; the hamlet, where they dwell and arrange for food; the village, where they develop industries in co-operation; the small 
town, where farmer, hamleteer, villager and townsfolk meet at market; the large town, towards which all the others contribute their stream of goods in exchange for the specialised goods of a still greater world; the great cities, which are the thoroughfares of continental civilisations. What may have been the sequence of the past in this locality or that, among this race or that, I am unable to say, because I have not studied the problem; but as one passes through the thinly-populated lands, or the hamlets, or the villages, or the small towns of Scotland, one sees endless indications of how every institution named has its roots in the primary need for food and warmth, or may we say of warmth alone, the primary condition that enables the child to convert food material into growing tissue.

\section{The Structural Basis of the Family Sentiment.}

But if we imagine history producing unending currents each having its origin in a new family of three, we are not long before we notice that, by the inter-relation of families, there comes a greater current absorbing the smaller currents. Some groups are more closely inter-related than others, until one sometimes finds, in isolated localities, a whole village of fathers, mothers, grandfathers, grandmothers, great grandfathers, great grandmothers, brothers, sisters, cousins, first cousins, second cousins, and so on in all the near and far blood relationships. When people are isolated, as in ocean rocks like St. Kilda, we may safely expect to find every inhabitant related by blood to every other. But these social islands are equally to be found in coast villages, or inland villages, so long as they are untouched by the great currents of trade. In the days before transit was easy, the most natural growth in Scotland, for example, was the clan (the English form of the Gaelic word for children); and, apart from the needs of defence, the clan meant essentially the individuals of nearest relationship. So long as transit was difficult, the territory of the clan was limited; the great family kept together; the minor families within it became more integrated in the little society, and the sense of obligation to one another and for one another was based in feelings that every necessity of every day tended to renew. There the memory of one another was renewed at sunrise every morning and passed into the dream-life every night; the meaning of father and mother and brother and sister and child and grandchild and grandfather and grandmother would assume in the feelings a full-bodied significance unknown to the casual and 
discrete life of the ages of rapid transit. If you go to the Outer Hebrides, you will find just those conditions as fresh and vivid as they could have been in the early Aryan civilisation. You will find grown men with the emotional habits of children; old men and old women feeling towards them as to their first infant; grandfathers, grandmothers, grandsons and granddaughters living in an atmosphere of family sentiment that knows only spontaneous service, not parental responsibility; only the actions flowing from affection, not the duties required by law; only the delight of common sacrifice, not a grudging assent to the exactions of an alien organisation; only the desire to help where need is, not the fear that help will kill gratitude. And it is out of such an atmosphere of family sentiment that the sacred obligations arise,sentiment of responsibility for children, the sentiment of duty to parents, the sacredness of blood relationship, the unconditional obligation of the group to preserve the individual. And not until the family numbers out-grow the family sentiment, and the individuals begin to lose touch, do we find any question raised of the child's duty to the parents or the parents' responsibility for the child. Where the social affections predominate, where love is lord, the question of duty needs no answer, because it is never asked; the child without mother is not motherless, because the great family provides for it; father, mother and child alike are always at home, the mother with her father and mother, the father with his mother and father, the child coming and going and tended by all.

\section{The Family Sentiment as affected by the City.}

But the day comes when the clan ceases to be adequate; for one reason or another, superficially named political, or industrial, or geographical, but fundamentally named the struggle for life, the day comes when the clan necessarily passes away. The individuals scatter up into new attachments. New aggregations form. Among others there comes the city, the modern city, which in the majority of cases grows out of the mass-organisation of modern manufacturing industry. Here comes a social growth almost morbid in the severity of its pressure on individuals. The great families cease to be possible. They break up into their minimal units and once more it is father, mother and child. But now, under the extreme pressure of hunger, they have separated from their closest blood relatives and must accept as their friends other detached units like themselves. But between these isolated units there cannot be 
the same intensity of family sentiment. The groups of three must do their best to keep that alive by the love of the one father for the one mother, the love of the two parents for the one child, neither sentiment having the support of the elders of the family group. Naturally, the family sentiment tends to atrophy. As naturally, the efficiency of the family tends to atrophy. What the great family group was able to do in the provision of food, of home, of education, of social service generally, the elemental families of three cannot achieve in the same fashion. And the child of each family must suffer, or a new method of service must be discovered.

But no two strata of society in a city are at the same stage of development. To the industrial family now reduced once more, under pressure of the mass-organisation, to the father, mother and child living in a room, there comes a voice from another stratum where the family sentiment has been kept alive by study and intercourse and an easier struggle for food. In this stratum, lives are longer, labour is easier, culture is higher, and the tradition of the family sentiment has all these to support it. The social worker whose duty it is to preserve the tradition of the elders does not cease to insist on the tradition even where the family has fallen to its minimal unity of three. He places on the physiological father and mother the same obligation for the child as, in the larger social group, he would have placed on the group as a whole. Not noting that the father and mother must work for many hours a day, unrelieved by any other member of the family, he yet demands of the over-burdened father all that only a man of leisure can provide, and of the over-driven mother all that only a woman of leisure can give. And he names the duty of the father and mother parental (not family) responsibility, attaching to it the full wealth of sentiment, the full emotion of obligation that he could legitimately have exacted only from the larger family group. Forgetting that he finds the family in conditions where the primary parental duties are impossible, he yet requires of the parents the impossible duties.

Naturally, the family fails. It can survive only by sacrificing the individual. Let us see how, in the struggle for existence, it creates a new mechanism for its own salvation. This new mechanism is the city.

V. Industrial aggregation of Families compels organisation of City.

Aggregation compels organisation, if the aggregating units 
are to survive. A mob of families, as in an ill-organised camp, means so high a death-rate that nearly all the children die. A better organised mob means a decreasing death-rate, a greater capacity for survival of the group, of the family. From the unorganised mob, moved by impulse, to the organised city, moved by law, the process is perfectly continuous. Land is limited. Houses are necessary. There must be streets to move by, space to give air and light, water to make cleaning and cleanliness possible, drains to remove soil, artificial light to reduce the dangers of darkness, and the thousand other mechanisms organic to the city. You can see that everywhere the ultimate object is to preserve the family. The city is the protecting cradle for the new-born child.

\section{The City as a Protective Social Growth for the Preservation of the Family.}

For the geographically isolated family, the farthest horizon is as far off as a man can go for his day's work and come again. When the horizon expands, families disintegrate for a time, but they create new organs to preserve themselves from extinction. The family is always the growing point of society. The derivative products are often mistaken themselves for independent growths and, when they are attacked, the unthinking person imagines that the whole fabric of society is falling to pieces. He fails to note that systems, institutions, special forms of social activity are but the deposits from an ever-flowing stream. Towns disappear and are built again. Countries are depopulated and filled again. Customs change, laws fall into disuse, but new customs come and new laws are made. It is the same irresistible instinct, the same desire, that creates every new society and will continue to create, to transform and re-create without end.

When, therefore, we talk of the decay of responsibility, we must speak subject to our knowledge of this invincible process of re-growth. The most stable society is a perpetual flux of men and institutions. History is a history of transits. We must, therefore, be prepared for endless transformations of things apparently most fixed; we must detach ourselves from the necessities of the moment if we would see how the affairs of the moment have come to be and if we would foresee what they will become.

Why has the relation of the city to the family been recently so much discussed? To answer this question fully would be to write the history of England since the Boer War began. Of the 
many results of the War, one has been the awakening of the people to the need for physical self-examination. For nearly twenty years, I might even say eighty years, the great public health movement has been preparing the public mind for an era of personal hygiene. When the War came, it revealed to millions what only few had suspected-that among the individuals of our race the standard of fitness is, if not too low for national safety, at least lower than it ought to be. The nation was staggered to find so many thousands of recruits rejected as unfit for the healthy, open-air life of the army. A whole train of problems flowed from this fact. It was discovered-what ought to have been common knowledge for fifty years - that the infantile mortality was preposterously high, that the homes were unclean, food unsuitable, preventable diseases largely unchecked; that children at school suffered from defects of senses, chronic diseases, acute diseases, all acting as obstructions to the compelled work of education; that physical deterioration, if not true degeneration, was everywhere so common as to justify more radical investigation; that even the essential fitness of the family as an institution was seriously impugned by large numbers of people. The conviction stole into men's minds that, if society is to be regenerated, the regeneration must begin with the infant. Hence our army of health visitors, the epidemic of milk depôts, the effervescence of charity organisation societies, and the hundred other embodiments of irrepressible social enthusiasm. Mothers are found ignorant of the elementary laws of infant rearing. Fathers are found careless of the primary rituals of nature. Fathers and mothers are found unfit to educate their children, or are found disinclined to concern themselves with the things of the mind. The children, it is found, are ill-nourished. They have too little sleep, too little air, too little house-room, too little clothing, too little attention from parent or friend. The cry at once arises,-Let us feed them. The House of Commons, in a generous fit, echoes, Feed them, and the House of Lords repeats the echo. Hence it is that the English Statutes to-day contain the possibility of a public table everywhere for the school-child and the parent is requested to pay where he can, and, if he cannot pay directly, he will be permitted to pay as a ratepayer.

Curiously, this issue has come as an immediate solution of a supremely difficult question. I am not here concerned with the adequacy of the solution, though grave doubts are justified : nor with the nature of the solution, which seems to have sprung up from nowhere and gripped men's minds with a firm conviction. 
I look at the matter merely as an accomplished social fact, just like the other manifestations of the family energy in the social growths flowing from it.

Two lines of thought have converged to produce this curious social result. One set of men keep insisting on the necessity for compelling the parent to attend to his child, to wash him, to feed him, to clothe him. They are, without doubt, asserting a great and primary duty. Another set of people keep insisting that the parent, if he is compelled by the State to perform certain duties, has equally the right to the service that will make his performance of these duties possible-public health service, education service, civic service generally. Here, too, we must admit, there is a certain truth. But while the Parentalists insist on the one aspect too abstractly, the Civicists insist too abstractly on the other. Both sides are committing an equal fallacy. They occupy different standpoints; but they both seem to speak from the same plane. For as the Parentalist insists on one truth-the duty of the parent, he forgets the other truth-the right of a parent; the Civicist equally insists on the one truth - the right of the parent, but forgets the other truth-the duty of the parent. But, in both cases, the parent is the centre of the contest. It is as a father that he claims a right; it is as a father that he has a duty imposed upon him. If, in the conditions of his life, he cannot rear his child as perfectly as a man should, he not unnaturally looks for the instruments that he shall use to help him and he not unnaturally forgets that it is on himself the duty lies to discover these instruments and to use them; it does not lie with the great mythical organisation that to him is the State. If, on the other hand, the Parentalist critic, knowing how much can be done by individual steadiness of character, insists that the father shall do more than he actually does, he not unnaturally presses too far the one aspect of responsibility and unintentionally exacts of the father what no single father can perform. The father and the critic fail to understand each other; they seem to be to each other unpardoning enemies, and hence our English feeding law (not yet our Scottish) has emerged out of a political contest where each side calls the other by foolish names and neither seems to see the end of the movement nor the principle of their own creed.

But if we go back to the primary nature of the family, if we satisfy ourselves that the city in all its specialisation, in all its organs, is after all but the body of which the family instinct is the soul, the enlarged organisation of which the family is the 
embryo, we shall find that the father and his critic can easily be reconciled. The father, in going to the public school to find education for his son, is not going to an alien association where he has no right; he is rather going to the office he himself has created, the organ of culture originating at the home but outgrowing the home in largeness of effect and in efficiency. Or when, himself taken by fever or finding that his child through some mischance takes fever, he goes to the public health authority with the intimation, he goes not to an alien authority needing some other impulse to set it in motion; he goes rather to the institution he himself has created just for this contingency and, handing over his child for the time, he has him taken into safe keeping for the necessary season. Neither in education nor in disease can the father do for his child all that a good father wants always to do for his child. A child needs a nurse; but not every father can provide one. The child needs a school-master; but with every will to teach, every father cannot succeed in teaching. Whether it be want of time, or want of energy, or want of knowledge, it matters not: the result is one and the same-the child loses in the race. To keep his child free from disease; to fit his child by education for the work of the complex society he is to live in,-these are two primary duties of the father and, except in the poorest, most insufficient way, he cannot of himself either mentally or physically perform either the one or the other. $\mathrm{He}$ is driven by every social force, by every social ambition, by every good impulse, to seek for a means to keep his child alive and to inform his child's mind. To require, without conditions, that every father individually shall provide hospital and school for his child is to throw our society back, to give up an immense privilege without providing any compensation. Any social theory cannot, if it insists on such impossibilities as these, be regarded as of any consequence. It does not do to assume that any single factor in the situation is fixed. The father must go forward or he must go backward; the child must grow or he must starve; disease goes on to a bad issue or to a good issue as it is ill-treated or well-treated; the mind goes on to efficiency or inefficiency as it is well-educated or ill-educated. These are not speculations; these are facts. And I choose the hospital and the school as two typical parental necessities, which the parent practically never can himself provide adequately, and, even when he is a well-paid artizan, he cannot provide them at all. Here he is driven remorselessly to seek the co-operation of the great organisations. The very condi- 
tions of his life, whether in a city or in the country, make any other course impossible. If we are to revert to the simple life of the clan, the reversal cannot take place unless we blot out whole stretches of our civilisation and even then the same problems will assert themselves for solution once more. Every age has its own special impossibilities. In our age, two impossibilities for the individual parent are the efficient hospital and the efficient school. Even the areas of individual towns and parishes are often found too small for efficient service of hospitals.

But what he cannot directly and individually provide, the parent provides indirectly through the city. What, however, he must learn to realise is that, whether produced by himself directly or by himself indirectly, the school and the hospital are equally his own; it is equally his duty to use them. By no other course can the physiological father and mother preserve the child from death or inefficiency. To survive functionally at all, the minimal group of three must use not merely the lesser, but also the greater, specialised family out-growths, which, in their aggregate, form the city.

\section{The Family Sentiment and the Civic Sentiment.}

The organisation of the city does not proceed in a straight line nor does it strike its roots everywhere at once. As Professor Patrick Geddes has shown us in his vivid way, the city has a prolonged growth embodying tens of thousands of various energies. And cities are not all of one cast. Rather they are aggregates of survivals from many civilisations. When, however, under the impulse of some powerful single motive the mass of a city's people are drawn into a certain unity of feeling and thought, we see what the potential organisation of the city is. We see how a people of approximately one stratum will organise more easily and more rapidly than the multi-stratified city so much better known to us. But, even in the "faults" of the multistratified city, we trace hints of organisation that leave us in no doubt of the city's origin or of the origin of the composite social group. But whether we contemplate the relatively simple city or the relatively complex city, we find equally that gaps are possible between a city organisation and the minimal family, not to speak of the enormous gaps between the city and the individual. By the illusion of projection, intensified a thousand-fold by the different histories of the various strata of families, the city organisation proceeds as if it were some great objective mechanism, not to be 
controlled by any human power. It is too great a thing for the individual man to regard as his own or the expression of himself. To be "a citizen of no mean city" is so high an ethical achievement that only the valiant patriot ever attains to it. And even he attains to it rather in feeling than in intellect. The revolution unmade a king, and made a consul; but he in turn, drawing his power primarily from the people, became the great projection of the people's mind and dominated for a generation his own creators. What we see so strikingly in Napoleon, we see also, but less strikingly, in every city. It is the same unconscious projection of collective power turning to dominate our feelings and imaginations. None the less is it true that the organisation created by multitudes of men, out of millions of individual impulses and ideas, is capable of becoming the imaginative expression of every one man's mind, the instrument of every one man's will. One great problem in our civic education is to teach the individual how to bridge the gap between himself and the city organisation,between himself, the abstract individual, and himself again, the organised city.

Put in this vaguely abstract way, the educational problem looks fanciful. But take a case. Look to the actual father and mother of a child suddenly smitten with an infectious disease. In a moment, they think of the doctor; then they take his advice. The doctor notifies the case to the municipality, whose officers, in a few minutes, are in attendance. Observations are made; records are taken; a nurse and an ambulance appear and in half an hour the child, under the care of two trained women and a surgeon, lies carefully watched in a dainty cot. Perhaps, within the hour, an operation to save his life has been completed and the immediate urgency is over.

Trace now the sequence of actions. The father and mother, vaguely educated, do not live in the categories of municipal theory; but they know that they can rely on the municipal service and they know what step to take to set the service in motion. They are thus, in a moment of stress, unconsciously united in feeling to the great organisation that makes the salvation of their infant's life possible. When, however, the child passes from the home to the hospital, there at once emerges a feeling of antagonism between the parents and the municipality. They are jealous of its actions; they suspect its motives; they find their child of immeasurably greater value than they had formerly known; they long for its preservation, for its restoration, for its reappearance in the home. 
On the other side, the municipal officers, forgetting, for the moment, the existence of the parents, lose themselves in devotion to the child. They bring all the science and skill and tenderness they can to bear on its salvation. They resent the intrusion of the parents; they take official possession of the child as if it belonged primarily to the city; they guard it jealously that no foolish mother shall spoil the treatment by over-indulgence and no foolish father gratify his fatherly sentiment at the expense of the infant's recovery. The parents have invoked a spirit that they cannot control. They have committed their child to it before they know how or when they shall receive their own again. In faith, they make the sacrifice; in faith, they await the result. When at last the infant, restored and healthy, goes home, the municipal officers place him among their statistics and the parents take him to their bosoms. The officers turn to others in more urgent need, carrying to them once more healing and service. The parents, absorbed once more in the lesser family sentiment, forget the city and all the prayers they raised to it in their need.

I have seen so often this sudden light of civic faith and this sudden darkness of civic infidelity, that I cannot but regard them as normal to the great mass of our incipient citizens. Hardly once in a long official experience have I found, among thousands, a parent that sustained, after the recovery and redelivery of his child, a shade of the same intensity of feeling as he showed on the first consciousness of danger. Now and again, out of conventional courtesy, a man has sent gifts to the hospital or to the nurse, associating everything with a person, nothing with the organisation that made the person functionally possible. Once or twice, I have seen a flow of grateful feeling that spread itself over an hospital staff, producing gifts for everybody and kind words that made duty a pleasure. But never have I seen any parent that frankly attributed to himself and his fellow-citizens the virtues that produce the city as an instrument for increasing the power of the family.

It is clear, therefore, that the gap in the mind is both intellectual and ethical. The ordinary man stops at the immediate person; he acts for the immediate person; he is grateful to individual persons; he turns from them to his own the moment the danger is over. On the other hand, the officers of a municipality tend to become official; more and more they imagine themselves individuals when their functional existence rests on a universal; more and more they act as if they held individual power when yet every 
activity is conditioned by the system they serve under. It should be possible to bridge the distance between these two extremes,- - to carry the father's impulse into a further development; to make the official realise that, through him, father and city are united in the child.

But the organisation of the city on the large scale risks the loss of the family sentiment by reducing the family to its minimum. As we have shown, the family sentiment has difficulty in surviving where only a father and mother and child are found together. The capacity for inter-suggestion is too limited. There is a want of atmosphere. At the same time, the very want of atmosphere generates the impulse to seek outside assistance in its readiest form and this is usually the civic doctor. On the other hand, the family sentiment where the family is large enough to sustain it effectively, asserts its ancient belief in the family capacity to serve all needs and tends to block the way to civic action. Over and over again have I met with obstruction to civic activity when the family sentiment was strong. This is probably the meaning of the long-continued refusal of the well-off classes to enter public hospitals. But everywhere this feeling is giving place to the readier acceptance of civic assistance. And as the readiness of acceptance has been hastened in the industrial areas by the mechanical reduction of the family capacity as the result of labour, so, in the wealthier orders, the family sentiment tends to evaporate with the increase of centrifugal tendencies in the individuals, ease of transit, separate living, boarding schools and the other mechanisms of functional disintegration. Intellectually, it is commonly accepted that, in a thousand ways, the family home cannot compete with the civic hospital or school; but in feeling, this position is not always accepted quite frankly. There is a remnant of conviction that civic assistance is a last resort and a proof of family failure. Yet even this is passing away and we find in some cities that every class of the community, rich and poor, not merely admit the usefulness of their public institutions, but imperiously demand their use. In Glasgow, for example, it is now not uncommon for the Medical Officer of Health to remove to hospital from 90 to Ioo per cent. of persons suffering from certain infectious diseases. This is done without compulsion. It is merely the municipal organisation acting in response to the wish of individual citizens. Infectious disease has always been a great educator and has taught civilisation many intimate truths. It continues to teach us, acting at once as a mechanically integrating 
force, and as a revealer of civic duty. More pointedly than any other normally present fact it shows how essential the city is to the realisation and to the safety of the individual. It indicates also how we should bridge the abyss of feeling that lies between family and city.

Many forms of civic administration are the subject of legitimate dispute; but the public health functions of the city everyone, at least in Scotland, now accepts in theory, if not in practice. Hence it is from public health that I have taken a typical illustration. Probably the rooted fear of personal danger has predisposed every community to accept the protection and restrictions of the public health administration; but what began under stress of fear has persisted and developed because of convenience. Fear made the path; cool convenience crowds it. More than once I have known a village thrown into panic by a single infectious case. To-day the same village is to a man ready to hand over a case to the hospital authorities. In the outlying places, terror still destroys the family bond and kills the impulse of neighbourliness; but the public health movement is none the less one of the most striking examples of growth in citizenship.

The accident that the fear of infection is a primary motive in winning men's minds to the movement, need not obscure the movement's inner nature. Were such a fear its only motive, the movement would die locally whenever the panic passes. And in the earlier days of local organisation, this was what occurred. In a minor degree, it still occurs. But the movement has much deeper roots than this apparent fear. The fear only revealed the inadequacy of the home to carry through the salvation of the child. Under stress of fear, the parent creates or discovers a new mechanism and thereafter he is ready always to use it. The home is saved from an impossible duty and the death-rate goes down.

The education movement has, superficially, a very different history; but fundamentally education and the public health movement both arise from the inadequacy of the home.

And so we might draw illustrations from all the great organisations that constitute a municipality. Each organisation could be traced back to some family need that could not be adequately provided for in any other way.

\section{Causes of the diremption of Family and City.}

The reasons why the family and the city have fallen apart have been vaguely indicated already. The stages may be briefly 
stated as follows:-First, there is the mass-organisation necessary for industrial evolution; second, there is the consequent disintegration of the family group into minimal families of three, with all the necessary limitations; third, there arises the necessity for representative administration, since, at an early stage of aggregation, the families become too numerous to act as a single council; fourth, there is the projection of the representative organisation as if it were an alien power. The representative organisation and its officers become a force controlling the very people that elect them. The electors always find it impossible to maintain in complete activity the belief that the men elected derive their power from the electors and from no other source; that, in fact, the representative bodies are simply the electors themselves acting in one capacity for a given purpose,-the concrete projection of the electoral mind. But, like all mental projections, sane or insane, the representative projection tends to become a fearsome and hostile obsession, a thing to be criticised, denounced and destroyed. Rarely, if ever, is it recognised as the product of the electoral mind itself. But since the city is worked just by this projected representative body, the elector, in his capacity as head of a family, almost necessarily considers the family and the representative bodies as antagonists to one another. Hence the primary difficulty in civic education is to restore to the citizen the lost sense of identity between the family and the representative body. $\mathrm{He}$ sees both family and city in abstraction from one another and accordingly he sees them entirely wrong.

\section{Parental Responsibility as affected by the City.}

The common conception of responsibility assumes that the child belongs to his father much as his house and furniture belong to him. The common conception, no doubt, is vague and we need not press it too much; but the common action and the common insistence on the duties of parents seem to presuppose that, if the child, all through his life, could be left entirely to the parents to bring up, to educate and to place on the world, the result would be the best possible whatever the parent's capacity for this gigantic task may be. This is another way of saying. that the whole course of city growth, the whole results of aggregation, are simply an unavoidable social disaster; not a beneficent opportunity for expansive organisation. But, right or wrong, the city is a social fact and we must take it as it is. We are not. 
here estimating political results or prospects; we are simply attempting to trace a principle among actual conditions.

But it is surely wholly erroneous to maintain that the child should be the exclusive care of the parents. To begin with, this is hopelessly impossible. At the best, the parents are simply social trustees for the child. They have no final authority to do with him as they choose. They must honour all the obligations they undertake in becoming parents. Among the first of their obligations, they have to learn that the child belongs not exclusively to them, but, through them, to the society they live in. Sooner or later, every parent learns this lesson; because the child grows to manhood or womanhood. Yet the lesson comes to every parent as a surprise and a revelation when the personality of the child firsts asserts itself. "Woman, wist ye not that I must be about my Father's business?" This is what every parent must face. But if he is educated, he foresees it and works towards it. He knows that this assertion of independent personality is at once the sign of manhood and the proclamation that the child, from the beginning, is not simply the son of his individual father, but also the son of Man.

But if the child is not simply and exclusively the property of the individual father, the father must be, from the beginning, under obligation to recognise this aspect of the child's life and to develop it. This, however, he cannot at any time do if he confines the child's environment to the immediate home and family of three. He must, from the beginning, take hold of all the instruments of culture, all the institutions of civilisation, all the organisations that tradition has specialised for the total culture of his child. His responsibility, therefore, is fully discharged to his child only when he does for it all that he individually can, first, immediately by his own powers in his individual home and next by his mediate powers in the school, the hospital, the city as a whole, to secure the nurture and education of his child towards full citizenship.

Here I am not concerned with any practical consequences that flow from the theory. That would lead me into politics, with which a Sociological Society has nothing to do except after the fact. What $I$ have sought here to indicate is that the actualities of our present practice demand something a little more subtle, a little more thorough-going, than the abstract parenthood and the abstract citizenship that have for so many years been filling us with weariness and confusion. 


\section{Illustration from Recent Edinburgh Investigation.}

If it were necessary to give a reason for discussing the family, it would be difficult to find one better than the recent investigation in Edinburgh. The analysed facts are given in the Report by the Edinburgh Charity Organisation Society. So far as I am aware, the central idea of that investigation, which was first proposed and sketched by Mr. Arthur Sherwell, M.P., is new in British social work. Usually, such an investigation starts from the home and radiates to the public institutions. In the present case, the investigation started with the school and sought for the history of the school-child in his home. Every child of a given school was medically examined with the greatest minuteness possible in the circumstances. Equally, his home and the remainder of his family were investigated economically. The child, thus examined, was then fitted into the home system of ascertained facts, which were verified along all the available lines of investigation. Some $78 \mathrm{I}$ families, involving approximately $\mathrm{I}, 400$ children of school age, were thus analysed in detail. The resulting wealth of facts is enormous, and will provide problems for many a year to come. In this paper I can deal only with the large generalities suggested by a pretty intimate knowledge of the concrete facts recorded. But I may detail two or three specific impressions that this investigation has made on some minds in the North.

First, there is the obvious fact that the family as we understand it does not carry through the work that we habitually assign to it. Read through the details of any of these family summaries and you will hardly find one where the physiological father and mother are equal to the load of duty placed upon them or, under legitimate impulse, undertaken by them. Even with perfect health, which is rare, with perfect character, which is rarer, and with perfect prudence, which is rarest, the men and women here involved almost all require the support of outside institutions and, when you consider the whole facts, you cannot say that any other course is possible. Let the conditions as they stand be right or let them be wrong; but as they stand, they make it impossible for two people, a father and a mother, to do by themselves more than a fractional share of what is due to the child. If you doubt this, scrutinise for yourselves the multitudinous details. Even when we eliminate drink, incapacity, debauchery, and all such vices of personal character, we are yet faced with the difficulty as to why a great city produces conditions that overwhelm the two most important individuals, the father and mother. 
Second, it seems clear that if the family did not seek the assistance of external organisations, it would sink into a lower degree of efficiency than even these investigations reveal. If there were no school, the child would not only be grossly neglected in body, but he would also be robbed of every chance of intellectual or ethical culture. If there were no dispensaries, he would not only suffer from the minor dirt diseases that dispensaries do not tackle, but he would go under in his multitudes to the stress of serious disease. If there were no hospitals, he would not only in sickness have to rely on the overcrowded and fœtid room where he was born, but he would also have for nurse the overdriven and uneducated mother. And so we might take him through other relations. In every one of them, but for the outside organisation, he would live only for a little time or, if he lived longer, he would not achieve even the moderate success he now does.

Third, it is not want of intelligence, or want of character, that can account for the failure of the family to do its work. It is not possible here to argue the question fully, but my impression is that this analysis of concrete cases merely reveals the extreme of which every family is an instance. It is only another example to us of the fact that no family of three can live by its own resources; but the example is so striking because the conditions of life are so stringent. In seeking external support for their energies, those families are doing only what every other family in its degree does.

Fourth, we cannot, therefore, simply say that, if the sense of parental responsibility were once restored, those conditions of failure would disappear. The conditions of failure are not peculiar to the poor ; they are true of every class. It is only that, among the poor, they become so obvious that none can doubt their existence and none ventures to deny the necessity for help.

Fifth, it may be that, on the extreme view, it were better that no external agency should offer any assistance to these failing families; but simply to say so is to beg the question. The broad fact is that of all these families scarcely one is self-sufficient. Let it be admitted that drink is a potent cause of failure, that thrift, as ordinarily understood, hardly exists, that a different early history might mean a different later history; but let us not suppose that, in offering these minor criticisms, we are altering the central fact, namely, that in this class of society, as in every other, the family cannot do for the child all that the child needs to fit it for citizenship. 
$\mathrm{XI}$. Restoration of the Family Sentiment by the mediation of the City.

The external alienation of the civic organisation from the family is largely an historical accident or rather an accident of irregular city growth. It is not a final obstacle to the restoration of the true civic feeling, which supervenes on the perception of the identity of city and family.

If we were to use Hegelian terms, we might say that, from the point of view of logic, the minimal family of three is mere Being or the immediate. It expresses itself, however, in the endless variety of appearance, or Existence, coming then under the categories of the ordinary life as it is lived in the city-houses, streets, tramways, shops, banks, stock exchanges, etc., etc. These all proceed as if they were themselves final embodiments of some idea; but they are, after all, if left to themselves, only a passing show. Slowly emerges the organisation of the city as a whole, creating its systems of officials with ever more and more differentiating duties. Then we see that what is here revealed is only what the family had within itself. And we attain to the Notion of the city, which is also the "truth" of the family. Perhaps this looks a little fantastic to the present positive-minded generation of science; but it is on the whole as good a way as any other of expressing the essentially organic nature of city and family. What appears merely mechanical, the result of several methods of voting or transit or finance, is fundamentally after all but the external form that some definite mental purpose has taken. The form is only the index of continual synthetic growth. Every new function that the city developes and, on trial, sustains, is but the sign of newly elaborated structures. And as the individuals whose massed activities have generated the great city all pass away, we are continually obsessed with the illusion that the city has come from some other than a personal source.

Is there anything in the functions of the city to check this obsession? I think there is. If only we had time habitually to reflect; we should find on every hand some reminder of the city's origin, some invitation to believe that its growth is one with our own, some stimulus to feel that the city offers a scheme for the highest realisation of the individual's activities. We could give many pointed illustrations. But perhaps those already given, the hospital and the school, are as striking as any. If you total up the functions of a great municipality like Glasgow, you will be amazed to find how many pages the mere enumeration will fill. 
And in a nation of cities like London, the civic unit-the familywould be hopelessly lost were it not that at every hand it is reasserted in the functions of the city.

More now than at any other period is it our duty to study the functions of the city in relation to the family. More now than at any other time in this country is the conception of the state as an external alien force passing into the conception of the state as the form of the expression of the general will. The abstract Statethe mysterious well-spring, whence all power flows-is slowly expanding into the concrete State-the focus of innumerable centres whence alone it derives its energy. In other words, Central Government and Local Government have in recent years grown up as a differentiating unity, until we hear men speak indifferently of State-feeding when they mean feeding by the parish or the municipality, and of State-maintenance when they mean that the municipality provides work for the unemployed.

In this turmoil of rapidly shifting concepts, it is natural that ancient landmarks should disappear; but it is the landmarks that disappear, not the land. The reality of the family is only becoming a hundred-fold more real as the functions of the family are more and more developed and specialised. For the moment, if the duty of the parent is confused, the duty preparing for him is greater and more exacting. Beyond the narrow horizon of his family of three, he sees, too, a horizon that fades for ever and for ever when he moves. But in the growing organisation, he is ever finding new revelations of what the potentialities are, new ways of increasing his own and their efficiency, new stimuli to active citizenship, new invitations to greater personal effort. All this, it is true, we find only now and then, in moments of social enthusiasm, at local elections, or when some great war excites the people; but none the less it is a reality and has in it the promise of great developments. The hopes and the fears that, in a system of city development, the family will be absorbed and superseded by some monstrous growth that destroys personality, sterilises ambition, and leaves every personal duty to someone else, are ungrounded in fact and incoherent in theory. Things do not happen in that way. It is only that the speculators in woods are lost for the trees. If we but analyse what is happening before our eyes, what is happening within our minds, what is happening in the streets outside, we shall not be long before we grasp the true significance of the city, which is the family grown, and of the family, which is the city growing. To restore the ethical unity of the two is the task of civic education.

W. Leslie Mackenzie. 


\section{LORD ACTON ON THE HISTORY OF FREEDOM.}

The two volumes of essays which have been published under this title serve again to remind us of the great loss which historical science has suffered by Lord Acton's death. These essays illustrate again, and in relation to many new subjects, the breadth of his knowledge and the keen analytical power of his mind. Lord Acton moves with almost equal ease and with just the same kind of critical discrimination in the region of contemporary political events as in those of former times; one or two of these essays, such as those on the Vatican Council, the Mexican Empire, and the Franco-Prussian War, are indeed extremely interesting examples of the treatment of contemporary politics in the manner, and with the analytical power, of the historical scholar. It is hardly necessary to say that these essays exhibit once again that astounding wealth of detailed knowledge which is the admiration and the despair of the humble historical student; there is, indeed, no modern historian who, on the centuries which succeed the mediæval period, has such an intimate knowledge of detail; there is no one whose acquaintance with the incidental literature of history can be put beside his. It is, however, perhaps to be regretted that the editors should have decided to republish all the essays contained in these two volumes, for, though all are learned, not all represent the maturity of Lord Acton's knowledge or critical judgment, and some of them hardly do full justice to his memory.

In this Review we are however not concerned so much with the historical essays in these volumes, as with those which deal with the history of liberty; the editors have rightly, indeed, recognised that many of the essays, while not directly bearing upon the subject, are yet clearly related to it, serve to elucidate or illustrate aspects of the opinions which are set out in the first two essays. And indeed they do this in a very notable fashion -essays such as those on the American Constitution and Civil War, or on the Inquisition serve to bring out very clearly what it was that Lord Acton understood by liberty.

It has been understood that Lord Acton had always contemplated a great work which should serve as a complete guide to the history of freedom; it is very lamentable that he was never able to begin this, and that we have nothing but these few lectures and essays to indicate the general nature of his scheme. 
These lectures do, however, present us with a view of the subject which, incomplete as it is, serves to give us some idea of the broad lines upon which his theory of liberty and of the history of the progress of liberty were conceived, and they also indicate very closely his conception of the dangers which threatened the further progress and development of freedom.

Certainly no historian ever set before himself a greater task, or one more worthy of the most strenuous labour. Here, indeed, we have something of the true philosophy of history, the attempt to get behind the mere record of change, to ask whether there are principles which lie behind the constant ebb and flow of historical conditions and relations.

It was indeed necessary that scientific history should shake itself clear of the abstract speculations of some eighteenth and early nineteenth century philosophic historians, or historical philosophers, it was necessary that men should approach the study of human actions and of human institutions without assuming some vast. system, into which it was already predetermined that all things must fit. To approach history with a determined and preconceived theory before there was any mass of strictly verified data upon which to work, was indeed to render all progress impossible. It was, therefore, necessary that the founders of modern scientific history, like Ranke in Germany and Stubbs in England, should resolutely refuse to pay any attention to the abstract systems, the abstract speculations, in history. And the incredibly rapid progress of scientific method and actual historic knowledge has more than justified the attitude of these founders of the method. To substitute a reasoned and careful consideration of the political, religious, and social forces out of which the new order of Europe has arisen for vague declamations and ignorant dogmatism, such was the work of Ranke; and to carry out an enquiry into the changes in English institutions, to show how these gradually grew from the simpler to the more complex forms, that has been the greatest achievement of the school of Constitutional historians, of whom, in England, Stubbs has been the leader.

We have now transcended the sceptical attitude in history, or, rather, we can leave that to the intelligent amateur. What we know, we know, and how little it is that we know, we also know, but we have found the clue to the treatment of political and constitutional development, and it is only the amateur or the ignoramus who doubts it. I could wish that I did not feel 
some doubt whether some of our historical scholars are not for the moment, it can only be for the moment, tending to fall back into that bog from which Ranke and Stubbs delivered us, into that morass of the method of mere enumeration of historical events. But this relapse can only be momentary, and serious historical scholarship has established itself permanently.

But now that we have so far reached our goal, that we have discovered our method, and that we view historic facts no longer as merely detached points, but as organically related to each other, now, I should venture to say, it is time that we should begin to think of the larger meaning of history, to see that behind the organic growth of constitutions behind the forces which at any given moment determine the nature of political relations, there lie greater principles still. The history of human society, as we read it, is not the history of an endless struggle of competing forces, but rather seems to present to us a slow movement towards the realization of some principles in which human nature finds its true development and expression.

It is very probable that for some time to come many historical scholars will be suspicious of this, will suspect that this is only the old philosophy of history, the old enemy come to life again. We must be prepared for this; every science has its own proper intellectual disease, and the disease of a merely archæological temper always threatens the historical student. And indeed we suffered much and greatly at the hands of the philosophical historian. But the world has changed, there is really no need to be afraid, the most timid historical scholar may lift his head up a little from his spade work, and will return to his labour all the better for having for a moment caught sight of the general plan of the ground on which he is working. And at least the technical scholar may be reassured when he sees that a man whose technical knowledge was superior to that of almost every one, is just the man who had conceived of history in the largest spirit and had set before himself the largest subject.

Lord Acton means by liberty much more than a share in the control of government; in one passage he defines it in the following terms :-

"By liberty I mean the assurance that every man shall be protected in doing what he believes his duty against the influence of authorities and majorities, custom and opinion."

The definition is, of course, too limited, and indeed it would seem to illustrate a somewhat defective training in the stricter 
methods of political philosophy. Lord Acton is evidently thinking of liberty almost entirely under the terms of freedom in moral and religious thought and action. His judgment would have been more complete and adequate had be learned to think of liberty in larger terms, in the terms of the full development of all the capacities and qualities of human nature; but while Lord Acton's phrase is somewhat narrow his meaning is sane and just, for his concern for religious and moral freedom is really a concern for that which seemed to him to be the highest form of self-expression. And even those who may have no special interest in the theological side of Lord Acton's definition, will easily recognise behind these phrases the conviction that the supreme purpose of social organization is to establish such a system of order as will enable a man to will and to live freely.

If Lord Acton's meaning is on this side just, it is also important to observe that he has seized the truth that in order to attain this moral and spiritual freedom man needs the protection of the social order, that though the true freedom is that of the soul, it cannot be attained and preserved except through the external organization of society. It may, perhaps, be doubted whether Lord Acton had attained to a completely organic conception of the relation between the individual and society; he is perhaps thinking mainly of the protection which society can give to the individual, and does not very clearly recognise the organic interrelation of the individual and the common life; while he recognises the need of protection he is perhaps hardly aware of the larger truth that in all the highest aspects of life as well as in the lower, man lives and acts through mutual support and co-operation between himself and his fellows. Perhaps it is the want of some clear conception of all this which renders his treatment of the history of freedom a little incoherent, so that while he treats of the progress of the recognition of the internal liberty of the soul alongside of the progress in political freedom, he does not quite succeed in reducing the history of the two aspects of freedom to a strict unity. But at least Lord Acton is wholly free from that confusion of mind which sets the progress of the freedom of the individual life in opposition to the progress of the organization of society.

The subject which Lord Acton had set before himself is really nothing else than the main subject of all sociological enquiry, the history of the development of the customs and institutions under which man strives to realise his complete personal individuality. For the progress of man is towards the 
completion of his own individuality, but this is conditioned by the fact that man is dependent for the possibility of progress on the society of his fellowman, and in order that this society may produce its proper results it must develop customs and institutions which are maintained and modified by its coercive authority.

The history of the progress of human society is therefore the history of the attempt, unconscious or deliberate, to find those institutions which at any given moment represent the highest attainable freedom for the individual, the attempt to provide through the organization of society the adequate basis for the most effective action of the individual.

Such is the subject which Lord Acton set before himself, and it was natural that he should deal with the subject primarily from the point of view of the freedom of religion. For to one who like Lord Acton finds in religion the highest term of a man's individuality and self-expression, anything which has the nature of restraint or coercion in the religious sphere must be specially abhorrent. It was, therefore, natural that, as against the somewhat vacillating judgment of many eminent historians, whose scientific method was not adequately reinforced by a firm grip upon first principles, he should very dogmatically maintain that religious persecution was the deepest crime against humanity and the greatest obstacle to progress. With characteristic freedom from merely traditional prejudice he denounces religious intolerance whether it was exhibited in the principles and practise of the mediæval church, or the reformed churches.

When now we examine Lord Acton's sketch of the progress of freedom we are compelled to recognise that his knowledge and comprehension are not always equally complete. His knowledge of the last four centuries is encyclopædic, and his judgment, if we except his attitude to the French Revolution, is not open to serious criticism, but his summary view of ancient history and thought is neither adequate nor convincing, and his treatment of mediæval history and thought is at best inadequate.

Lord Acton rightly lays great stress on the importance of the doctrine of the law of nature in the Stoics and Cicero and the great jurists of the Digest; he rightly recognises that this doctrine is the form under which these thinkers apprehended the principle that the rights of human nature are not measured by civil laws, but have their foundation in conditions and possibilities which lie beyond the sphere of the sovereign power. But I venture to think that Lord Acton makes a profound mistake 
when he thinks that this doctrine is not already the central point both of the Aristotelian and Platonic theory of society. Those who have asked themselves seriously what is meant by the Platonic discussions of the nature of justice, or who have understood the real significance of the Aristotelian test which is to distinguish the good from the bad constitution cannot fail to understand that not only Rousseau in the "General Will," but also the Stoics in the "Natural Law" are reproducing the great principles which were first set out by Plato and Aristotle. When, therefore, Lord Acton says :- " We are seeking out the influences which brought arbitrary government under control, either by the diffusion of power, or by the appeal to an authority which transcends all government, and among these influences the greatest philosophers of Greece have no claim to be reckoned "-it is evident that he had never clearly understood what were the main principles of the great Greek philosophers. It is no doubt true that the later philosophers of the ancient world represent a great advance on the earlier in their conception of personality, and a writer like Cicero represents a great progress in the apprehension of the organic relation of the freedom of the soul to self-government in the political sphere. But that is not the same thing as to say that Plato and Aristotle did not understand the difference between an arbitrary government which acts as it pleases, and a government which represents the supremacy of principles which lie behind political power, or that Aristotle did not understand the practical value of the organisation of government under such forms as would secure the "common control," while they also would tend to check the dangers of popular government.

It is the more strange that Lord Acton should have fallen into this mistake about the great Greek philosophers, for in his treatment of the development of the Athenian constitution he has urged that it is there that we came to that supremely critical moment at which men began to recognise the supremacy of law over arbitrary power, and that it is there also that we find the first beginnings of the progressive development of the machinery of self-government.

If Lord Acton fails to understand the debt which the theory of political freedom owes to the greatest of the ancient thinkers, he does ample justice to the contribution of the Stoics, and to the great jurists who embodied much of the principles of their political philosophy in the Roman jurisprudence. We cannot indeed overestimate the importance, in the history of civilisation, 
of the fàct that the jurists, following partly the Stoics, partly still older Greek definitions of the nature of law, set out so emphatically the principle that law is not any command of the sovereign but only such commands as are proper deductions from or applications of eternal and immutable principles to the circumstances of a particular time and place. These principles inherited by the civilians and canonists of the Middle Ages and developed by the political thinkers of those times did much to counteract the mischievous tendency to confuse power with authority.

Lord Acton's treatment of the influence of Christianity on the progress of freedom is in the main admirable. It is no doubt true and it is always worth while to restate it, that the separation of religious from secular authority was one of the main elements in the development of a complete conception of human liberty. This was not due so much to the fact that the struggle between the Church and the Temporal power during the middle ages contributed to the development of the constitutional liberties of Europe, but rather to the claim of the Christian conscience that in the highest form of life, that is, in the spiritual sphere, the state cannot legitimately claim any authority at all. This is indeed the reason why to the enquirer into the history of freedom the most memorable documents in the early history of the Church, are the tractate and the epistle of Pope Gelasius, in which he laid down the great principle that while the church and the State are both Divine institutions, neither of them has any authority within the sphere of the other. It is no doubt true that in the great struggle between the Empire and the Papacy it might seem as though men had forgotten this, but the principle survived the struggle and vindicated liberty of conscience at least against the State.

It is possible that Lord Acton overestimated the influence of the great struggle between the church and the secular power in furthering the progress of constitutional freedom. The forces which were making for this were in action before the struggle developed and apart altogether from this. The truth is that the constitutional movement of the Middle Ages represents the normal development of the principles and characteristics of the political organisation of the Teutonic societies, which we can trace clearly from the time when these societies began to assume a definite form. As early as the ninth century we can see that the constitutional movement was in full progress, and even that men were conscious 
of this; and it is important to observe that the development of the movement was most rapid and complete in England where the opposition of church and State was least important.

It must also be remembered that the ancient jurisprudence had handed down to the mediæval world the principle that the people are the only ultimate source of political authority. This is the real explanation of the fact that Thomas Aquinas and Marsilius of Padua, the one representing the ecclesiastical tradition, the other the secular, agree in laying down the general principles of constitutional freedom.

The treatment of the development of personal and political freedom in modern times seems to me admirably handled, until Lord Acton comes to the French Revolution and the political theory of Rousseau, but there I must think that sometimes he has been unable to take into account the main features of history and of theory, and has been unduly influenced by certain aspects of the history, and by a mistaken reading of the theory. It is probably true that the French Revolution did not shake off completely the superstition of an absolute sovereign power in the State, and that consequently the constitutional governments of modern Europe have not fully learned the limits of political authority. But to say, as Lord Acton says in his lecture, "I would have wished to show you that the same deliberate rejection of the moral code which smoothed the paths of absolute monarchy and of oligarchy, signalised the advent of the democratic claim to unlimited power "- this is really paradox passing all reasonable limits, and has no claim to be taken as serious historical criticism. And Lord Acton's failure to understand that Rousseau in the "Contrat Social " laid the foundation of the very principle which he is himself striving to express, is almost incomprehensible. For Rousseau in the "Contrat Social" set out once again to lay down the greatest of all political principles, that the authority of the State rests upon a moral basis, and represents the necessary means by which men are to rise from the merely animal to the truly human life, and that the principle which binds men together in the society of the State must combine the highest freedom of the individual with the greatest efficiency of the whole society.

I have seemed to lay stress mainly upon the defects of the essays; and I think that it is necessary to point out their defects, for so great and so justly great is the reputation of Lord Acton as a historian and a moralist that it is to be expected and to be 
hoped that these essays will be widely read, and that their influence will be long felt.

But when we have recognised these defects I should hope that the example of the essays, the breadth and dignity of their principles will command the attention of all historical students; and that the task which Lord Acton had set before him may some day be resumed and carried out to its conclusion.

A. J. Carlyle. 